\title{
Audit of caesarian deliveries in a tertiary care center, in rural Bangalore, India
}

\author{
Rajiv K. Saxena*, Anju Balan
}

Department of Obstetrics and Gynecology, MVJ Medical College and Research Hospital, Hoskote, Bangalore, India

Received: 24 January 2019

Accepted: 05 March 2019

\section{*Correspondence:}

Dr. Rajiv K. Saxena,

E-mail: drrajivsaxena@yahoo.com

Copyright: (C) the author(s), publisher and licensee Medip Academy. This is an open-access article distributed under the terms of the Creative Commons Attribution Non-Commercial License, which permits unrestricted non-commercial use, distribution, and reproduction in any medium, provided the original work is properly cited.

\begin{abstract}
Background: The Robson's Ten-Group Classification System allows critical analysis of caesarean deliveries according to characteristics of pregnancy. The objective was to analyze caesarean section rates in a rural tertiary care teaching hospital in Bangalore, using Robson's ten groups classification.

Methods: This study was done in MVJ Medical College and Research Hospital, a rural tertiary care teaching hospital. All patients who underwent caesarean delivery, between November 2017 and October 2018, were included in the study. Women were classified in 10 groups according to Robson's classification. For each group, authors calculated its relative contribution to the overall caesarean rate.

Results: The overall caesarean section rate was $46.7 \%$. The main contributors to this high caesarean rate were primiparous women in spontaneous labour (group 1) and women with previous caesarean section (group 5). 52.1\% of CS were conducted on women who were unbooked or booked at a peripheral health facility and referred to present institution due to complications in labor. Strategies to lower CS rates would include encouraging women with previous CS, to undergo trial of labor to reduce CS rates for group 5C. Sensitization of staff in peripheral medical facilities for early referral of high-risk pregnancies to a tertiary care center for better control of medical complications like hypertensive disorders of diabetes mellitus. Other strategies include offering external cephalic version to eligible women with breech presentation and consider offering vaginal breech delivery to suitable women in groups 6 and 7 .

Conclusions: The Robson's classification is easy to use. It is time to implement obstetric audit to lower the overall CS rates.
\end{abstract}

Keywords: Caesarean section rates, Clinical audit, Robson's classification, Ten group classification system

\section{INTRODUCTION}

Clinical audit is an important means to improve patient care through critical analysis and review of available data. The rising caesarean section (CS) rates have assumed epidemic proportion and need evidence-based strategies to safely reduce unnecessary CS in every institution. Dr Michael Robson, in 2001, proposed the need to adopt a standard classification system for easy comparison and bringing about evidencebased improvement in obstetrics care. He introduced Robson classification, also called ten group classification system (TGCS), to standardise this clinical audit across different institutions. ${ }^{1,2}$ The size of the TGCS groups, and the CS rates in each group of this classification, contributes to the overall CS rate of the institution.

The World Health Organization (WHO) and the International Federation of Gynaecology and Obstetrics (FIGO) recommend the Robson TGCS as a standard for monitoring and comparing CS rates within heath care facilities. ${ }^{3,4}$ 
The aim of this study was to initiate the collection of data and use of TGCS as a starting point to audit caesarean deliveries in present institution.

\section{METHODS}

This was a prospective observational study of all women delivered by caesarean section at MVJ Medical College and Research Hospital, Hoskote, Bangalore. This institution is a tertiary care, teaching hospital, and a referral centre for neighbouring private and public health facilities in the rural Bangalore district.

\section{Inclusion criteria}

- All women delivered by CS during the study period of twelve months, from November 2017 to October 2018.

The demographic data and obstetric details, including pregnancy outcome were tabulated according to TGCS and analysed for this study. There was no exclusion criteria. Ethical clearance for the present study was obtained from the institutional ethics committee.

\section{Statistical analysis}

Descriptive statistical analysis was done, and percentages calculated.

\section{RESULTS}

All patients who delivered by CS, were grouped according to Robson TGCS using maternal characteristics and obstetric history. The Robson system classifies all deliveries into one of ten groups on the basis of five parameters: obstetric history, gestational age, onset of labor, fetal lie, and number of fetuses.

The whole sample was distributed into these mutually exclusive groups. For each group, authors calculated its relative size and its contribution to the overall caesarean rate. The characteristics of each group of TGCS is presented in Table 1.

\section{DISCUSSION}

When medically justified, a CS can effectively prevent maternal and perinatal mortality and morbidity. CS is the recommended mode of delivery in transverse lie or nullipara with breech presentation, and it is considered appropriate and justified for this category of women. However, in women where CS is done purely on maternal request, without a medical indication, CS cannot be considered as appropriate or justified. When CS is done for foetal distress, sometimes on delivery the foetus is depressed and has to be admitted to neonatal intensive care unit (NICU) for its survival, whereas, at other times the foetus is born healthy and with good Apgar scores. Hence, CS for this category of women is always a dilemma for the obstetrician. Women with previous scarred uterus make up another debatable category for CS. All categories of women contribute to the overall CS rate of the institution. Hence, it has been suggested that the overall institutional CS rate should no longer be thought of as being too high or too low, but rather, whether they are appropriate or not.

This study was an attempt to use Robson TGCS to audit caesarian sections in present institution, and to understand the reasons behind the CS rates for different groups of TGCS specific to present institution.

The overall CS rate of present institution for the twelvemonth study period was $46.7 \%$ i.e. 955 CS of 2043 total deliveries. Authors studied the demographic characteristics of the women admitted to present labor room to gain insight into this high CS rate. Women who were unbooked in present institution or booked in peripheral health facilities and referred to present institution due to a complication of labor, contributed significantly to the overall high CS rate. Around $52.1 \%$ $(n=498)$ of CS were conducted on this group of women. Many of these cases were referred on weekends and outside of 'working hours', presumably due to nonavailability of facilities for CS or staff at these peripheral health facilities. Ninety percent i.e. 150 of 167 neonatal admissions to NICU, after CS, were from this group of women.

Arpita et al, also reported a high overall CS rate of $44.61 \%$ from another large teaching hospital in north Karnataka, which is also a referral hospital for the neighboring population. As pointed out by the authors this high rate of CS reflected the hospital CS rate and not the population CS rate. ${ }^{5}$ Anita Kant reported a CS rate of $53.86 \%$ in their institution from Faridabad, in Haryana, India, which is also a tertiary care institution where there are large numbers of referred high risk cases. ${ }^{6}$

The first group of TGCS is traditionally a large group, and therefore, accounts for a sizable percentage of the overall CS rate. Twenty six percent $(n=248)$ of CS were done in nulliparous women in spontaneous labor at term, indicating that authors are dealing with a relatively highrisk population in group 1 of TGCS. This group also accounted for $24 \%$ of NICU admissions amongst all the neonates born by CS. Women booked elsewhere and referred to present institution for CS due to complication of labor made up $71 \%(n=176)$ of this group. Almost half of these high-risk women $49.4 \% \quad(n=87$ of 176) underwent CS for fetal distress, other common indications for referral to present institution were arrest of dilatation and non-progress of labor. 
Table 1: Modified Robson ten group classification system (TGCS).

\begin{tabular}{|c|c|c|c|c|c|}
\hline Group & Description & Data & $\begin{array}{l}\text { Total } \\
(\mathrm{n}=955)\end{array}$ & $\begin{array}{l}\text { Referred from } \\
\text { outside }(n=498)\end{array}$ & $\begin{array}{l}\text { NICU admission } \\
(\mathrm{n}=167)\end{array}$ \\
\hline 1 & $\begin{array}{l}\text { Nullipara, single, cephalic, equal to } \\
\text { or }>37 \text { weeks-spontaneous labour }\end{array}$ & $\begin{array}{l}26 \% \\
(n=248)\end{array}$ & $\begin{array}{l}26 \% \\
(n=248)\end{array}$ & $\begin{array}{l}71 \% \\
(n=176)\end{array}$ & $24 \%(n=40)$ \\
\hline \multirow[t]{2}{*}{2} & $\begin{array}{l}\text { Nullipara, single, cephalic, equal to } \\
\text { or }>37 \text { weeks } \\
\text { A: Induced }\end{array}$ & $\begin{array}{l}10.5 \% \\
(\mathrm{n}=100)\end{array}$ & \multirow{2}{*}{$\begin{array}{l}15.9 \% \\
(\mathrm{n}=152)\end{array}$} & $\begin{array}{l}44 \% \\
(n=44)\end{array}$ & $\begin{array}{l}3.6 \% \\
(\mathrm{n}=6)\end{array}$ \\
\hline & B: CS before labour & $\begin{array}{l}5.5 \% \\
(n=52)\end{array}$ & & $\begin{array}{l}61 \% \\
(n=32)\end{array}$ & $\begin{array}{l}3.6 \% \\
(\mathrm{n}=6)\end{array}$ \\
\hline 3 & $\begin{array}{l}\text { Multipara, single, cephalic, equal to } \\
\text { or }>37 \text { weeks-spontaneous labour }\end{array}$ & $\begin{array}{l}5.1 \% \\
(n=49)\end{array}$ & $\begin{array}{l}5.1 \% \\
(n=49)\end{array}$ & $\begin{array}{l}56 \% \\
(n=27)\end{array}$ & $\begin{array}{l}10.1 \% \\
(n=17)\end{array}$ \\
\hline \multirow[t]{2}{*}{4} & $\begin{array}{l}\text { Multipara, single, cephalic, equal to } \\
\text { or }>37 \text { weeks } \\
\text { A: Induced }\end{array}$ & $\begin{array}{l}1.7 \% \\
(n=16)\end{array}$ & \multirow{2}{*}{$\begin{array}{l}3.9 \% \\
(\mathrm{n}=37)\end{array}$} & $\begin{array}{l}31 \% \\
(\mathrm{n}=5)\end{array}$ & $\begin{array}{l}3 \% \\
(n=5)\end{array}$ \\
\hline & B: CS before labour & $\begin{array}{l}2.2 \% \\
(\mathrm{n}=21)\end{array}$ & & $\begin{array}{l}71.4 \% \\
(n=15)\end{array}$ & 0 \\
\hline \multirow{3}{*}{5} & $\begin{array}{l}\text { Previous CS, single, cephalic, > } 37 \\
\text { weeks } \\
\text { A: Spontaneous labour }\end{array}$ & $\begin{array}{l}10.1 \% \\
(\mathrm{n}=96)\end{array}$ & \multirow{3}{*}{$\begin{array}{l}36 \% \\
(\mathrm{n}=344)\end{array}$} & $\begin{array}{l}45.4 \% \\
(n=44)\end{array}$ & $\begin{array}{l}5.4 \% \\
(\mathrm{n}=9)\end{array}$ \\
\hline & B: Induced & 0 & & 0 & 0 \\
\hline & C: CS before labour & $\begin{array}{l}26 \% \\
(n=248)\end{array}$ & & $\begin{array}{l}28 \% \\
(n=69)\end{array}$ & $\begin{array}{l}3 \% \\
(n=5)\end{array}$ \\
\hline 6 & $\begin{array}{l}\text { All Nulliparous Breech } \\
\text { A: Spontaneous labour (4) } \\
\text { B: Induced } \\
\text { C: CS before labour }\end{array}$ & $\begin{array}{l}1.3 \% \\
(n=12)\end{array}$ & $\begin{array}{l}1.3 \% \\
(n=12)\end{array}$ & $\begin{array}{l}100 \% \\
(n=12)\end{array}$ & $\begin{array}{l}3.6 \% \\
(n=6)\end{array}$ \\
\hline \multirow{3}{*}{7} & $\begin{array}{l}\text { All Multipara Breech (including } \\
\text { previous CS) } \\
\text { A: Spontaneous labour }\end{array}$ & $\begin{array}{l}0.6 \% \\
(n=6)\end{array}$ & \multirow{3}{*}{$\begin{array}{l}1.8 \% \\
(\mathrm{n}=17)\end{array}$} & $\begin{array}{l}100 \% \\
(n=17)\end{array}$ & 0 \\
\hline & B: Induced & 0 & & & 0 \\
\hline & C: CS before labour & $\begin{array}{l}1.1 \% \\
(n=11)\end{array}$ & & 0 & 0 \\
\hline \multirow{3}{*}{8} & $\begin{array}{l}\text { All Multiple pregnancy (including } \\
\text { previous CS) } \\
\text { A: Spontaneous labour }\end{array}$ & $\begin{array}{l}0.3 \% \\
(n=3)\end{array}$ & \multirow{3}{*}{$\begin{array}{l}1.5 \% \\
(n=14)\end{array}$} & $\begin{array}{l}100 \% \\
(n=14)\end{array}$ & $\begin{array}{l}1.8 \% \\
(n=3)\end{array}$ \\
\hline & B: induced & 0 & & 0 & 0 \\
\hline & C: CS before labour & $\begin{array}{l}1.1 \% \\
(\mathrm{n}=11)\end{array}$ & & $\begin{array}{l}27 \% \\
(\mathrm{n}=3)\end{array}$ & $\begin{array}{l}1.8 \% \\
(\mathrm{n}=3)\end{array}$ \\
\hline 9 & $\begin{array}{l}\text { All abnormal Lies (including } \\
\text { previous CS) } \\
\text { A: Spontaneous labour } \\
\text { B: Induced } \\
\text { C: CS before labour }\end{array}$ & $\begin{array}{l}0.3 \% \\
(n=3)\end{array}$ & $\begin{array}{l}0.3 \% \\
(n=3)\end{array}$ & $\begin{array}{l}100 \% \\
(n=3)\end{array}$ & $\begin{array}{l}1.8 \% \\
(n=3)\end{array}$ \\
\hline \multirow{3}{*}{10} & $\begin{array}{l}\text { All single, cephalic, }<37 \text { Weeks } \\
\text { (including previous CS) } \\
\text { A: Spontaneous labour }\end{array}$ & $\begin{array}{l}4.6 \% \\
(n=44)\end{array}$ & \multirow{3}{*}{$\begin{array}{l}8.2 \% \\
(n=79)\end{array}$} & $\begin{array}{l}73 \% \\
(n=32)\end{array}$ & $\begin{array}{l}21 \% \\
(n=35)\end{array}$ \\
\hline & B: Induced & $\begin{array}{l}0.6 \% \\
(n=6)\end{array}$ & & $\begin{array}{l}100 \% \\
(n=6)\end{array}$ & $\begin{array}{l}3.6 \% \\
(n=6)\end{array}$ \\
\hline & C: CS before labour & $\begin{array}{l}3 \% \\
(n=29)\end{array}$ & & $\begin{array}{l}60 \% \\
(n=17)\end{array}$ & $\begin{array}{l}13.7 \% \\
(n=23)\end{array}$ \\
\hline
\end{tabular}

Women in group 2A where labor was induced, constituted $10.5 \%(n=100)$ of overall CS rate in present institution. Indications for induction of labor were varied. However, within this group the commonest indication $(n=94)$ for induction was "postdates", i.e. beyond the expected date of delivery. Eighty percent of women $\left(n=75\right.$ of 94) in this group were induced between $40^{\circ}$ and $40^{6}$ weeks, only $20 \%$ were induced labor at $41^{0}$ weeks of 
gestation or beyond. NICE guidelines recommend that these women should be offered induction of labor between $41^{\circ}$ and $42^{0}$ weeks, to avoid the risks of prolonged pregnancy. Maternal anxiety and family pressure to hasten the delivery process, as well as, obstetricians desire to avoid sudden fetal demise often contribute to induction before $41^{0}$ weeks of gestation. This group contributed to only $3.6 \%$ of NICU admissions amongst all the neonates born by CS during the study period.

Some systematic reviews state that the risk of CS is not increased due to induction of labor, however, the procedure itself is not without risk. Recently, Mahomed et al reported from a retrospective cohort study, involving only nulliparous women with uncomplicated singleton pregnancy at $40^{0}$ to $41^{6}$ weeks, that incidence of CS was significantly higher in the induction group at $40^{0}$ to $41^{6}$ weeks when compared to women with spontaneous labor at $40^{0}$ to $41^{6}$ weeks. ${ }^{7}$ Counselling by senior obstetrician and adhering to guidelines may see more women progress to spontaneous labor and thus avoid unnecessary inductions and CS in this group of TGCS.

Group 2B were primipara who underwent CS before the onset of labor and contributed to $5.5 \%(n=52)$ of present overall CS rate. Jacob et al, from Thrissur Medical College, reported similar contribution of this group i.e. $6.2 \%$ of CS rates in their study. ${ }^{8}$ Tanaka, from Australia, found that this group contributed only $0.5 \%$ to their overall CS rate. $^{9}$

In present institution, women referred from other health facilities contributed to $61 \%(n=32)$ of this group. The commonest indication for CS was 6-8 h of prelabour rupture of membranes, and/or ultrasound demonstrated severe oligohydramnios and patients unwilling for induction of labor. Some women in this group desired caesarian delivery on maternal request (CDMR). This group also contributed to $3.6 \%$ of NICU admissions amongst all the neonates born by CS during the study period.

Group 3 contributed to $5.1 \%(n=49)$ of present overall CS rate. The common indications were fetal distress and arrest of dilatation. present figures for this group are higher than those reported in other studies $0.4 \%, 1 \%$, $1.04 \%$ and $2.1 \% .^{5,6,7,9}$ The probable reason for this high figure is that $56 \%(n=27)$ of this group were unbooked women who were referred from other health facilities. $30 \%$ ( $n=8$ of 27 ) of these women declined augmentation of labor and opted for CS on maternal request.

Group 4 constituted $3.9 \%(n=37)$ of present overall CS rate. The common indications were "postdates", prelabour rupture of membranes and hypertensive disorders. $31.8 \%$ of women in this group, declined to continue with induction and desired CS on maternal request. Other studies have stated similar contribution from this group, $2.1-2.4 \%$ to their overall CS rate. ${ }^{5,8}$
Group 5 with previous CS pregnancy at term, was the largest contributor with $36 \%(n=344)$ of the overall CS rate. Group 5C, CS before labour, made up $72 \%(n=248)$ of group 5. $15.3 \%(n=38$ of 248$)$ of this group had previous two or more CS. Authors did note however that $91 \%$ of women with one previous CS, elected to have a repeat CS. Only 2 women had VBAC during the study period and they were admitted to labour room in an advanced stage of labour.

Even though vaginal birth after one CS has been advocated as a safe option, the number of women who attempt trial of labour after caesarean has declined over recent years due to fear of uterine rupture, as well as, the fear of litigations, amongst the care givers, in case anything goes wrong. ${ }^{10-15}$ Figures for group 5 reported in other studies vary between $10.9 \%$ and $40.1 \%$. $^{7,9,19}$

Increasing CS rate among women with breech presentation is a common phenomenon particularly since the publication of the term breech trial, and present hospital is no exception. ${ }^{16,17}$ Groups 6 and 7 consist of women with breech presentation and show a high CS rates. Despite the criticisms of the term breech trial, many hospitals, including ours, have been reluctant to offer vaginal breech birth. ${ }^{17,18}$ Other authors from different corners of the country have reported a $100 \%$ CS rate for groups 6 and 7.6,19 Even though this group is relatively small, authors should be more proactive in offering external cephalic version to all eligible women with breech presentation and consider offering vaginal breech delivery to suitable women.

Group 8 had 14 CS for twin gestations. There were two vaginal twin deliveries during the study period. There were only three CS for malpresentations in group 9.

Group 10, women birthing before 37 weeks, contributed to $8.2 \% \quad(\mathrm{n}=79)$ of present $\mathrm{CS}$ rates. This group contributed to $38.3 \%(n=64)$ of NICU admissions from the study population. Preterm labor, hypertensive disorders and gestational diabetes mellitus were the main contributors to this group. Around $69.6 \%$ of this group were unbooked women or booked in peripheral health facilities and referred to present institution in labor. Sensitization of staff in peripheral medical facilities for early referral to a tertiary care center for better control of medical complications like hypertensive disorders or diabetes mellitus may see a reduction in this group. Group 10 contributed $4.4 \%, 7.4 \%$ and $9.7 \%$ to the overall institutional CS rates in different studies from India. ${ }^{5,6,19}$

Around $23.1 \%(n=12)$ women in group 2B, technically qualified for the diagnosis of 'Caesarian Delivery on Maternal Request' (CDMR). The American college defines CDMR as primary prelabour caesarian delivery and is done on maternal request without any maternal or fetal indication. An additional $12.9 \%(n=45)$ women in groups 1 and $2 \mathrm{~A}$ opted to discontinue labor or induction process purely on maternal request. Moreover, $17 \%$ 
$(\mathrm{n}=11)$ multiparous women with previous vaginal delivery, in groups 3 and 4A decided to discontinue labor or induction and opted for CS on maternal request. Time specific delivery, as desired by some families, accounted for a meager $0.3 \%(n=3)$ of present $C S$ rate. All inclusive, $\mathrm{CS}$ on maternal request is a large group of women that push up the institutional overall CS rate. Anita Kant reported $10.4 \%$ of their CS rates was contributed by CS on maternal request. ${ }^{6}$ The predominant reason for maternal request was the desire to avoid labor pains. Institutional policy of offering counselling for these families and offering labor analgesia, as a routine, will certainly help to contain these numbers.

Women in group 2A need further analysis. A large study on singleton, cephalic term pregnancies in spontaneous labor concluded that active labor with cervical dilatation of 0.5 to $1 \mathrm{~cm}$ per hour only begins after $6 \mathrm{~cm}$ dilatation. The current concept of active labor beginning at $4 \mathrm{~cm}$ dilatation of cervix has been challenged. It may take longer than currently expected normal time frame for many women to reach $6 \mathrm{~cm}$ cervical dilatation. ${ }^{20,21}$ Hence $44.4 \%(n=44)$ of women in this group underwent CS for arrest of dilatation. They all started induction of labor with unfavorable cervix but the cervical dilatation at which CS was undertaken was not recorded. It is possible that some women may have had CS for failure to progress, when they had not even begun active labor. Discussion and consensus on progression of labor for each woman allotted to this group will reduce overall CS rates. Similar analysis for group 4A would yield rich dividends.

The proportion of women who had previously had a caesarean section increased in most countries across the world. $^{22}$ It would be prudent to explore measures to decrease primary CS for women in groups 1, 2, 3 and 4 . This will, in time, effect the overall CS rates in group 5.

Where facilities exist, trial of labor after cesarean (TOLAC) should be offered to women with previous CS after proper patient selection and counseling. This is the only way to reduce CS rates in group 5.

Robson TGCS is simple and reproducible classification, but also has certain limitations. It does not take into account the indications for induction of labor or CS, e.g. abruptio placenta or preterm eclampsia, where CS is considered a lifesaving procedure. It also does not account for pre-existing medical, surgical or foetal disease and the degree of prematurity; all of which may influence the decision to undertake CS. No information regarding women who have undergone trial of labor after CS (TOLAC) is obtained from TGCS. Many modifications to TGCS have been proposed to overcome these deficiencies, but none has gained universal acceptance nor stood the test of time..$^{8,23,24}$

Limitation: Authors did not capture detailed data related to vaginal deliveries during the study period, hence, data was incomplete to calculate the size of each group and its contribution to the overall cesarean delivery rate.

\section{CONCLUSION}

The use of Robson TGCS is recommended for medical audit in all maternity suits. Authors have used TGCS as the starting point for baseline data for audit in present institution, and authors intend to repeat the process over time to monitor the change in CS rates and improve quality of patient care.

\section{ACKNOWLEDGMENTS}

Authors would like to thank all the postgraduate students and staff of Department of Obstetrics and Gynaecology, MVJ Medical College and Research Hospital, Hoskote, Bangalore, for their wholehearted effort in data collection and support during the study.

Funding: No funding sources

Conflict of interest: None declared

Ethical approval: The study was approved by the Institutional Ethics Committee

\section{REFERENCES}

1. Torloni MR, Betran AP, Souza JP, Widmer M, Allen T, Gulmezoglu M, et al. Classifications for cesarean section: a systematic review. PLoS One 2011;6(1):e14566.

2. Betran AP, Vindevoghel N, Souza JP, Gülmezoglu AM, Torloni MR. A systematic review of the Robson classification for caesarean section: what works, doesn't work and how to improve it. PLoS One. 2014;9(6):e97769.

3. World Health Organization. WHO Statement on Caesarean Section Rates. WHO/RHR/15.02; 2015.

4. FIGO working group on challenges in care of mothers and infants during labour and delivery. Best practice advice on the 10-group classification system for cesarean deliveries. Int $\mathbf{J}$ Gynaecol Obstet. 2016;135:232-3.

5. Reddy AY, Dalal A, Khursheed R. Robson ten group classification system for analysis of cesarean sections in an Indian hospital. Res J Obstet Gynecol. 2018;11:1-8.

6. Kant A, Mendiratta S. Classification of cesarean section through Robson criteria: an emerging concept to audit the increasing cesarean section rate. Int $\mathbf{J}$ Reprod Contracept Obstet Gynecol. 2018;7:4674-7.

7. Mahomed K, Pungsornruk K, Gibbons K. Induction of labour for postdates in nulliparous women with uncomplicated pregnancy-is the caesarean section rate really lower?. J Obstet Gynaecol. 2016;36(7):916-20.

8. Jacob KJ, Jayaprakash M, Hibina KP. TMC (Thrissur Medical College) modified Robson criteria for caesarean sections. Int $\mathbf{J}$ Reprod Contracept Obstet Gynecol. 2017;6:5038-43. 
9. Tanaka K, Mahomed K. The Ten-Group Robson Classification: A single centre approach identifying strategies to optimise caesarean section rates. Obstet Gynecol Int. 2017;2017.

10. Royal College of Obstetricians and Gynaecologists, Birth after Previous Caesarean Birth (Green Top Guideline 45), RCOG, London, UK, 2015.

11. The Society of Obstetricians and Gynaecologists of Canada (SOGC), "Guidelines for vaginal birth after previous caesarean birth,” 2005. Available at: http://sogc.org/wpcontent/uploads/2013/01/155ECPGFebruary2005.pdf.

12. The American College of Obstetricians and Gynecologists (ACOG), "Vaginal birth after previous cesarean delivery," 2010. Available at: http://www.acog.org/Resources-And-

Publications/Practice-Bulletins/Committee-on-

Practice-Bulletins-Obstetrics/Vaginal-Birth-After-

Previous-Cesarean-Delivery.

13. Grobman WA, Lai Y, Landon MB, Spong CY, Rouse DJ, Varner MW, et al. The change in the VBAC rate: an epidemiologic analysis. Paediatr Perinatal Epidemiol. 2011;25(1):37.

14. Yeh J, Wactawski-Wende J, Shelton JA, Reschke J. Temporal trends in the rates of trial of labor in lowrisk pregnancies and their impact on the rates and success of vaginal birth after cesarean delivery. Am J Obstet Gynecol. 2006;194(1):144-e1.

15. Peel A, Bhartia A, Spicer N, Gautham M. 'If I do 1015 normal deliveries in a month I hardly ever sleep at home.' A qualitative study of health providers' reasons for high rates of caesarean deliveries in private sector maternity care in Delhi, India. BMC Preg Childbirth. 2018;18:470.

16. Hannah ME, Hannah WJ, Hewson SA, Hodnett ED, Saigal S, Willan AR, et al. Planned caesarean section versus planned vaginal birth for breech presentation at term: a randomised multicentre trial. Lancet. 2000;356(9239):1375-83.
17. Hehir MP. Trends in vaginal breech delivery. J Epidemiol Community Health. 2015;69(12):1237-9.

18. Glezerman M. Five years to the term breech trial: the rise and fall of a randomized controlled trial. Am J Obstet Gynecol. 2006;194(1):20-5.

19. Dhodapkar SB, Bhairavi S, Daniel M, Chauhan NS, Chauhan RC. Analysis of caesarean sections according to Robson's ten group classification system at a tertiary care teaching hospital in South India. Int J Reprod Contracept Obstet Gynecol. 2015;4:745-9.

20. Zhang J, Troendle JF, Yancey MK. Reassessing the labor curve in nulliparous women. Am J Obstet Gynecol. 2002;187(4):824-8.

21. Zhang J, Landy HJ, Branch DW, Burkman R, Haberman S, Gregory KD, et al. Contemporary patterns of spontaneous labor with normal neonatal outcomes. Obstet Gynecol. 2010;116(6):1281.

22. Vogel JP, Betran AP, Vindevoghel N, Souza JP, Torloni MR, Zhang J, et al. Use of the Robson classification to assess caesarean section trends in 21 countries: a secondary analysis of two WHO multicountry surveys. Lancet Glob Health. 2015;3(5):e260-70.

23. Farine D, Shepherd D. Classification of caesarean sections in Canada: the modified Robson criteria. J Obstet Gynecol Canada. 2012;34(10):976-9.

24. Prameela RC, Farha A, Bhanumathi PM, Prajwal S. Analysis of caesarean section rate in a tertiary hospital according to Robson's ten group classification system. IOSR J Dent Med Sci. 2015;14(2):46-9.

Cite this article as: Saxena RK, Balan A. Audit of caesarian deliveries in a tertiary care center, in rural Bangalore, India. Int J Reprod Contracept Obstet Gynecol 2019;8:1408-13. 